\title{
The influence of the combined effect of draught and radiant thermal asymmetry on human performance
}

\author{
Balázs András-Tövissi ${ }^{1, *}$, László Kajtár ${ }^{1}$, and Pawel Wargocki ${ }^{2}$ \\ ${ }^{1}$ Budapest University of Technology and Economics, Department of Building Services and Process Engineering, Budapest, Hungary \\ ${ }^{2}$ Technical University of Denmark, Department of Civil Engineering, Lyngby, Denmark
}

\begin{abstract}
Currently, there are studies which show the separate effect of the local discomfort parameters such as the draught and radiant thermal asymmetry. However, no studies have been conducted to find out the combined effect of the before mentioned two discomfort parameters on human performance. In order to fill this gap, a 17 months experiment was performed at the Budapest University of Technology and Economics. Throughout the experiment twenty human subjects (ten women and ten men) performed different cognitive tests and responded to questionnaires. Two different draught rates and five different radiant thermal asymmetry values were imposed in the Macskásy climate chamber, where the experiment took place. The results show the consequence of the combined effect of draught and radiant thermal asymmetry on the human performance.
\end{abstract}

\section{Introduction}

As building service engineering reglementations become stricter by the day, the heating demand decreases constantly. This makes office buildings with ceiling heating very reasonable. The limitations of ceiling heating systems consist in the fact that the temperature of the heating surface can be raised only above a certain surface temperature value - due to the local discomfort caused by the asymmetric radiation. The most commonly encountered discomfort factors in the case of the currently built office buildings are the draught and the asymmetric radiation.

The percentage of people predicted to be bothered by draught is shown by the Draught Rate (DR) in percent. The dissatisfaction regarding the hot ceiling is quantified by the percentage of dissatisfaction related to a given radiant thermal asymmetry, which in this case represents the temperature difference between the ceiling and the floor. The effects of these discomfort factors are known separately, but their combined effect is still unknown (Bánhidi and Kajtár, 2000; Barna, 2012). Diagrams 1 and 2 show the separate effect of the draught and the radiant thermal asymmetry (Fanger, 1970).

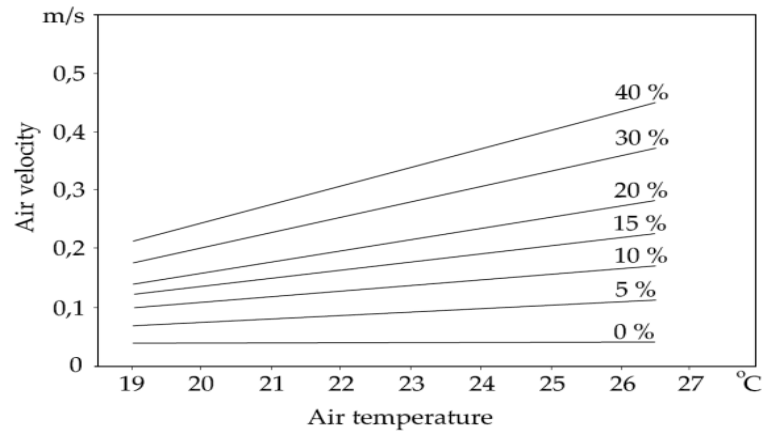

Diagram 1. Effect of the draught

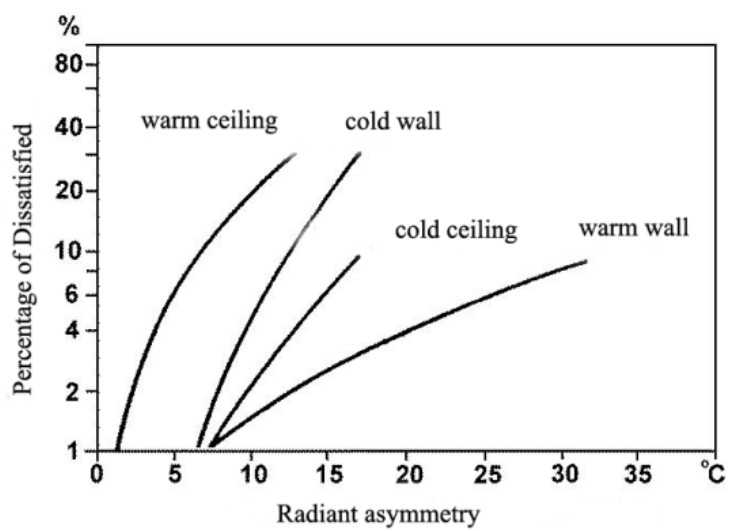

Diagram 2. Effect of the radiant thermal asymmetry

The purpose of the present paper is to identify and examine the effects of the microclimate made up of the previously mentioned 2 local discomfort parameters on people and especially on their task solving and working capacity. We were mostly focusing on the speed and accuracy of the work, under different asymmetry and draught effects. The current paper shows the results at $15 \%$ DR. Throughout our research we were focused on finding the answers to the following questions:

- $\quad$ is the temporal change of speed and accuracy rather similar, or does the increase in speed lead to a decrease in accuracy?

- Is the change of speed and accuracy similar in case of men and women?

\section{Methods}

The research of the combined effect of warm ceilings and the draught was carried out at the Macskásy Comfort and Air Conditioning Laboratory of the Budapest University of Technology and Economics. The

\footnotetext{
* Corresponding author: andras_balazs@yahoo.com
} 
measurements have been carried out throughout 17 months, whereby winter case was investigated.

\subsection{Determination of the inside surface temperature}

The limit of ceiling heating is determined by the degree of asymmetric radiation between the ceiling and the floor. Ceiling heating must cover the sum of the transmission and infiltration heat losses. In our case, we have modeled an office limited by outer glass wall on all of its sides, and by a floor underneath it, heated in tempering mode.

The surface temperature of the ceiling will be highest in the case of maximum transmission losses, since this is when highest rate of the energy loss must be compensated. Furthermore, the required surface temperature of the ceiling is determined by internal heat gains. By increasing the internal heat gain, the surface temperature required to neutralize the heat loss of the space decreases.

We assumed that the outside temperature is $-15^{\circ} \mathrm{C}$, which is the lowest design outside temperature in Hungary, and the temperature of the office underneath the examined space operated in tempering mode is 10 ${ }^{\circ} \mathrm{C}$, the $\mathrm{U}$ value of the window is $1.15 \mathrm{~m}^{2} \mathrm{~K} / \mathrm{W}$, which is the mandatory value for windows in Hungary and the $\mathrm{U}$ value of the floor is $0,8 \mathrm{~m}^{2} \mathrm{~K} / \mathrm{W}$, the temperature of the walls is $20,52{ }^{\circ} \mathrm{C}$, the temperature of the floor is $20,4^{\circ} \mathrm{C}$. During the measurements, $20.5^{\circ} \mathrm{C}$ was also set in case of the floor, so the surface temperature of each building structure excepting the ceiling was $20.5^{\circ} \mathrm{C}$.

A comprehensive instrument testing was carried out in the comfort chamber prior to the start of the human subject testing. The methodology of instrumental measurement and the comfort chamber are presented in Section 2.2.

\subsection{Instrumental measurements}

During the measurements, the Predicted Mean Vote (PMV) model was used to evaluate the thermal comfort. According to the PMV model, the thermal comfort is influenced by six parameters: air temperature, average air velocity, air humidity, mean radiant temperature, human activity level and heat insulation of the clothing. The effect of the draught was evaluated using the Draught Rate (DR) parameter, which is a function of the air's temperature, average velocity and the intensity of turbulence.

The research was carried out in a thermal comfort chamber with a surface area of $4 \times 4 \mathrm{~m}$ and a height of $3 \mathrm{~m}$. The scheme of the thermal comfort chamber and the chosen measurement points is shown in Figure 1.

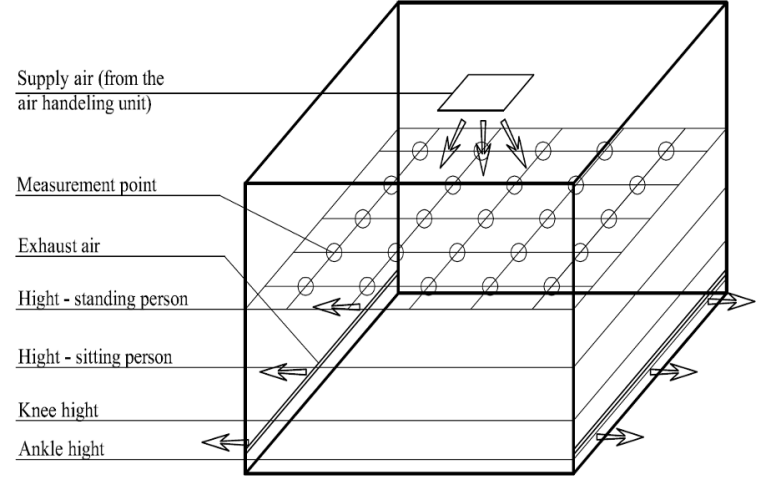

Figure 1. Scheme of the comfort chamber

One part of the parameters affecting the thermal comfort was measured, another part was calculated. Table 1 shows data for the different parameters.

Table 1. Data for the different parameters

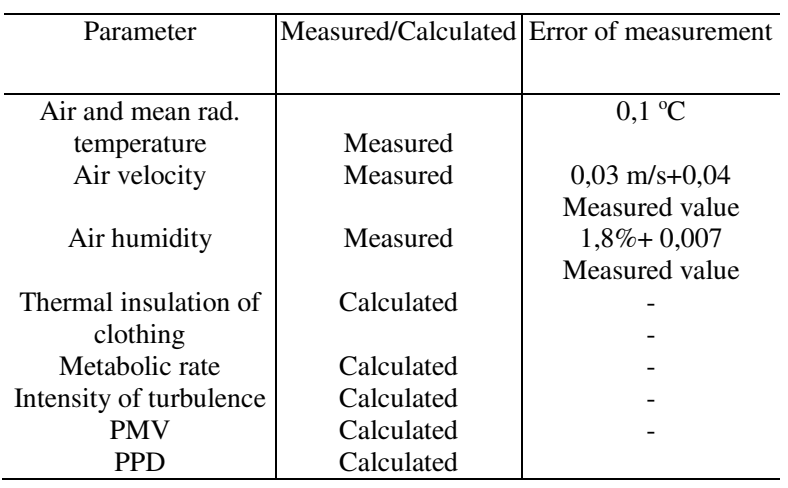

In order to determine the human response to the different comfort environments generated by the measured distributions of the influencing parameters, human subject experiments were required.

\subsection{The methodology of the human subject experiment}

In the planning of the human subject experiment, we have considered the methods used and recognized in the international practice (Toftum, 1995, 2002; Wyon, 2003). In accordance with these, 20 healthy adults participated in the research: 10 men and 10 women. The subjects were young people between the ages of 20 and 30.

A total of 10 parameter groups were tested, each human subject being exposed to 5 asymmetry and 2 draught values. The exposure was 3 hours (180 minutes) in each case, preceded by a 30-minute acclimatization period.

During a given session, human subjects were exposed to the effect of only one parameter group. The parameter groups were randomly selected in each session. By doing so, we prevented the subjects from discovering any lawfulness behind the changing of parameters. 
The parameter groups were constant in every session, each measurement was carried out in a steady-state condition and for each measurement there was only one person in the measurement space. Acoustic or air quality interference was excluded by reducing the noise from the ventilation system and by the high ventilation flow rate.

During the session, eating was forbidden; drinking water was allowed at any time. During the measurement, the chamber could not be left - a requirement which the subjects could fulfill. During the session, six blocks of 30 minutes each followed each other for a total of 3 hours. During this 3-hour period the comfort parameters were constant and the following activities were performed during each block: free activity, productivity test, thermal vote questionnaire and participation in a physiological test.

The present paper deals with the effect of the local discomfort parameters on the human performance. We measure human work performance by measuring the temporal change of work speed and accuracy.

\section{Results}

\subsection{Comfort parameter distribution}

The aim of the instrument measurements described in Section 2.2 was to create an appropriate thermal comfort environment in a certain point of the space. In order to assess the combined effect of the local discomfort parameters, the value of PPD in the middle of the examined space, at a height of $1.1 \mathrm{~m}$, should be less than 6 . This should be done while maintaining the asymmetry between the ceiling and the floor, as well as keeping the draught rate at a given value.

We calculated the values of PMV and PPD according to ISO (International Organization for Standardization) 7730, and the DR values were calculated as described in "ASHRAE" (American Society of Heating, Refrigeration and Air-Conditioning) Application Note AF-142. With this method, each parameter group was attributed a distribution in the space: at ankle height, knee height, as well as the height of the head of a person sitting or standing.

Diagrams 6, 7, and 8 show the distribution of PMV, PPD and DR at a height of 1.1 meters with the asymmetry between floor and ceiling at $10{ }^{\circ} \mathrm{C}$, and the draught rate at $15 \%$.

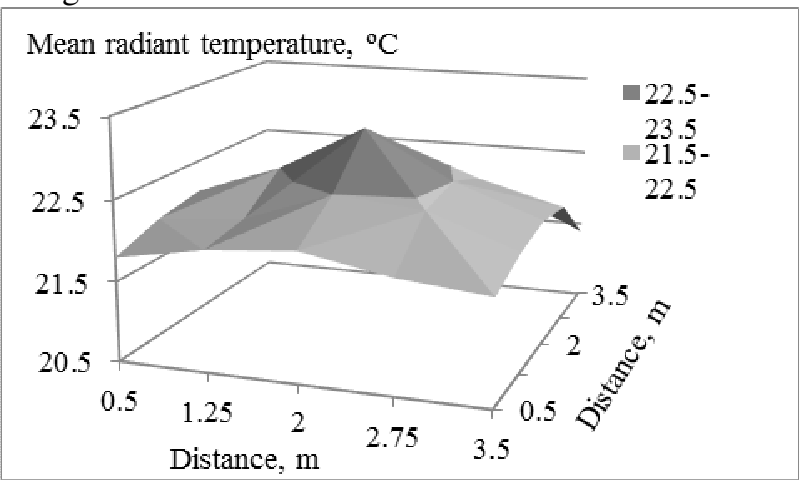

Diagram 3. Mean radiant temperature distribution

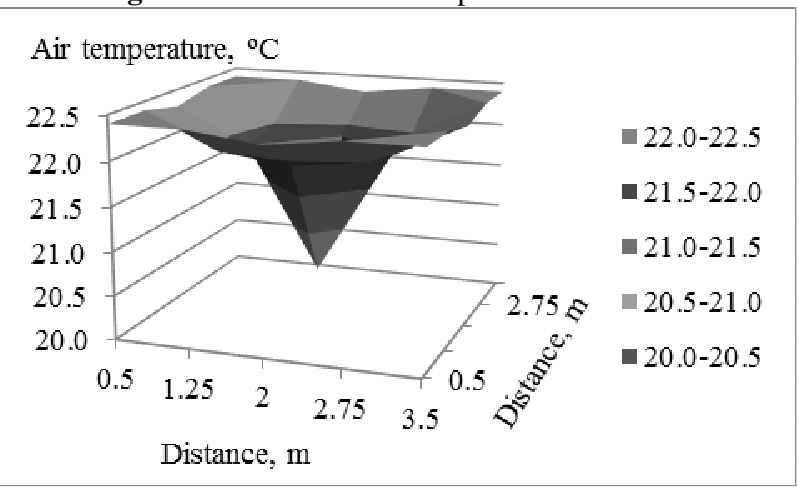

Diagram 4. Air temperature distribution

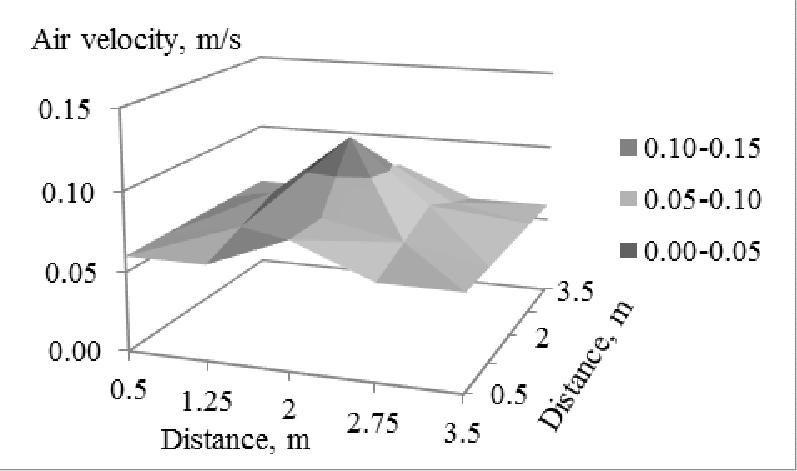

Diagram 5. Air velocity distribution

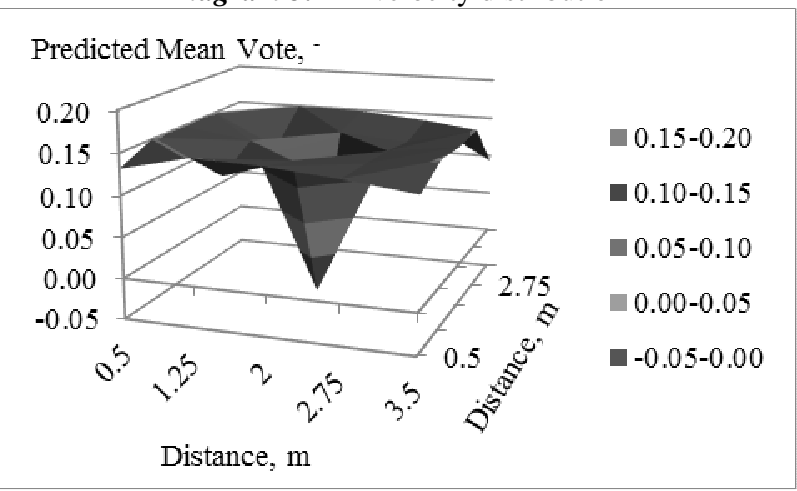

Diagram 6. PMV distribution

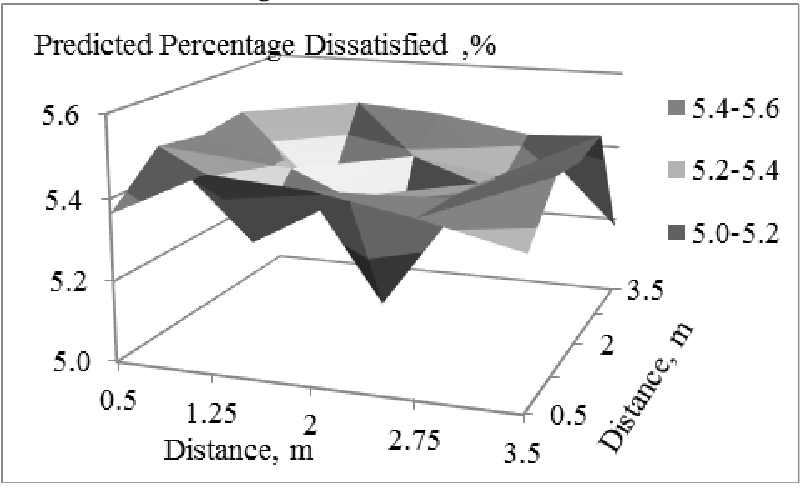

Diagram 7. PPD distribution 


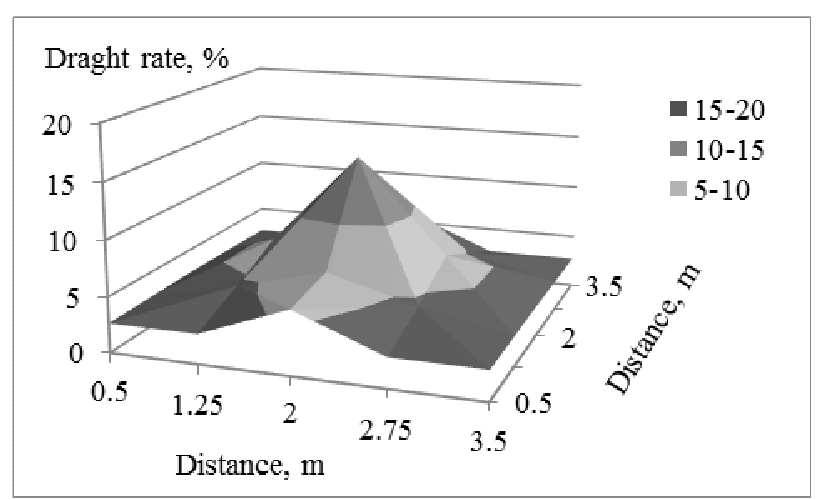

Diagram 8. DR distribution

In accordance with the presented distributions, the combined effect of the draught and the radiant thermal asymmetry can be examined. This was possible because the effect of both local discomfort parameters can be observed. The thermal comfort is nearly ideal at the center of the space (where the human subjects were sitting during the measurement), according to the PMV model, $(-0.2<$ PMV $<0.2$ and PPD $<6)$.

\subsection{Human response to the combined effect of thermal asymmetry and draught}

The change of human work performance was measured by observing the temporal change of speed and accuracy. Diagrams 9-15 show the temporal change of speed and accuracy in different cases. Each point of Diagrams 9-12 shows the average of 10 measurement points. We have fitted a curve on each of these points; furthermore, these diagrams also show the curves fitted on the external points of the $95 \%$ confidence interval.

Tables 2-5 show the equations of the curves fitted on the data points and on the extreme points of the confidence intervals, as well as the increase of the R2 depending on the degree of the curve.

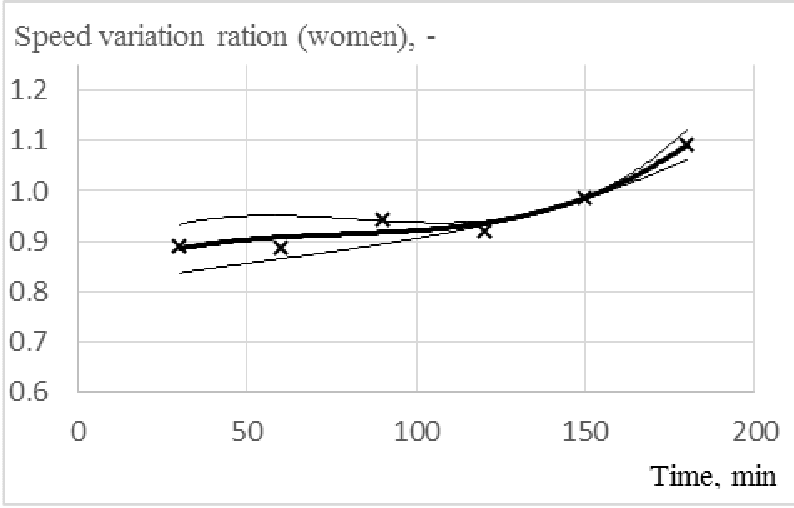

Diagram 9. Speed variation (women)

Table 2. Equations of the fitted curves - speed variation women

\begin{tabular}{|c|c|c|c|}
\hline $\begin{array}{c}\text { Type of the } \\
\text { curve }\end{array}$ & $\begin{array}{c}\text { Rank of } \\
\text { the eq. }\end{array}$ & Equation of the curve & R2 \\
\hline Curve fitted on & 1 & $0.001 x+0.87$ & 0.58 \\
\hline
\end{tabular}

\begin{tabular}{|c|c|c|c|}
\hline \multirow{2}{*}{$\begin{array}{l}\text { the upper } \\
\text { confidence } \\
\text { interval }\end{array}$} & 2 & $2 * 10^{-5} x^{2}-0.0024 x+1.01$ & 0.87 \\
\hline & 3 & $\begin{array}{c}2 * 10^{-7} \times 3+6^{*} 10^{-} \\
{ }^{5} \mathrm{x}^{2}+0.0043 \mathrm{x}+0.85\end{array}$ & 0.96 \\
\hline \multirow{3}{*}{$\begin{array}{l}\text { Curve fitted on } \\
\text { the data points }\end{array}$} & 1 & $0.0012 x+0.82$ & 0.79 \\
\hline & 2 & $10-5 x^{2}-0.0012 x+0.92$ & 0.92 \\
\hline & 3 & $\begin{array}{c}10^{-7} \times 3+3^{*} 10^{-} \\
{ }^{5} \mathrm{x}^{2}+0.0028 \mathrm{x}+0.83\end{array}$ & 0.95 \\
\hline \multirow{3}{*}{$\begin{array}{l}\text { Curve fitted on } \\
\text { the lower } \\
\text { confidence } \\
\text { interval }\end{array}$} & 1 & $0.0015 x+0.78$ & 0.9 \\
\hline & 2 & $7 * 10^{-6} x^{2}-3 * 10^{-5} x+0.83$ & 0.92 \\
\hline & 3 & $\begin{array}{c}5^{*} 10^{-8} \mathrm{x}^{3}+8^{*} 10^{-} \\
6 \mathrm{x}^{2}+0.0014 \mathrm{x}+0.8\end{array}$ & 0.94 \\
\hline
\end{tabular}

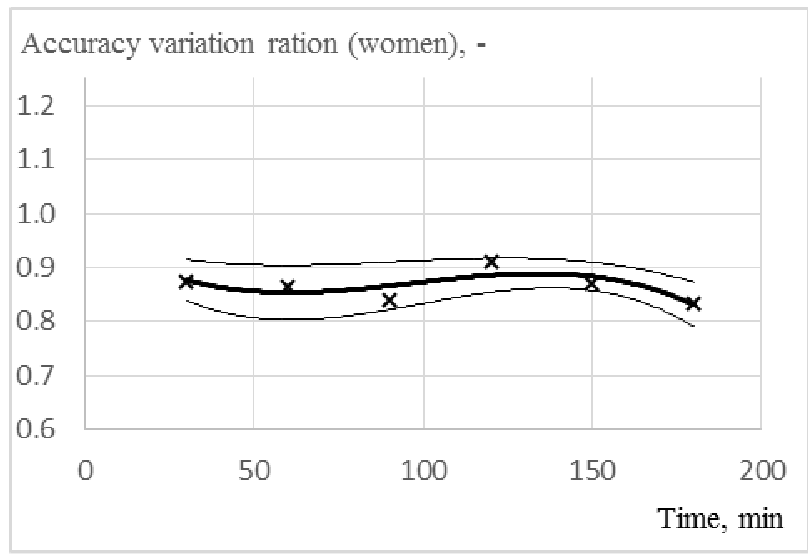

Diagram 10. Accuracy variation (women)

Table 3. Equations of the fitted curves - accuracy variation (women)

\begin{tabular}{|c|c|c|c|}
\hline $\begin{array}{l}\text { Type of the } \\
\text { curve }\end{array}$ & $\begin{array}{l}\text { Rank of } \\
\text { the } \\
\text { curve }\end{array}$ & Equation of the curve & $\mathrm{R} 2$ \\
\hline \multirow{3}{*}{$\begin{array}{l}\text { Curve fitted on } \\
\text { the upper } \\
\text { confidence } \\
\text { interval }\end{array}$} & 1 & $-0.0002 x+0.92$ & 0.13 \\
\hline & 2 & $-4 * 10^{-6} x^{2}+0.0006 x+0.89$ & 0.24 \\
\hline & 3 & $\begin{array}{c}-10^{-7} x^{3}+3 * 10^{-5} x^{2}- \\
0.0021 x+0.96 \\
\end{array}$ & 0.36 \\
\hline \multirow{3}{*}{$\begin{array}{l}\text { Curve fitted on } \\
\text { the data points }\end{array}$} & 1 & $-0.0001 x+0.88$ & 0.05 \\
\hline & 2 & $-4 * 10^{-6} x^{2 * 0.0007 x+0.84}$ & 0.18 \\
\hline & 3 & $\begin{array}{c}-2 * 10^{-7} x^{3}+5^{*} 10^{-5} x^{2}- \\
0.0043 x+0.97\end{array}$ & 0.56 \\
\hline \multirow{3}{*}{$\begin{array}{l}\text { Curve fitted on } \\
\text { the upper } \\
\text { confidence } \\
\text { interval }\end{array}$} & 1 & $-5 * 10^{-5} x+0.83$ & 0.01 \\
\hline & 2 & $-4 * 10^{-6} x^{2}+0.0008 x+0.8$ & 0.12 \\
\hline & 3 & $\begin{array}{c}-3 * 10^{-7} \mathrm{x}^{3}+8^{*} 10^{-} \\
{ }^{5} \mathrm{x}^{2}+0.0065 \mathrm{x}+0.97\end{array}$ & 0.77 \\
\hline
\end{tabular}




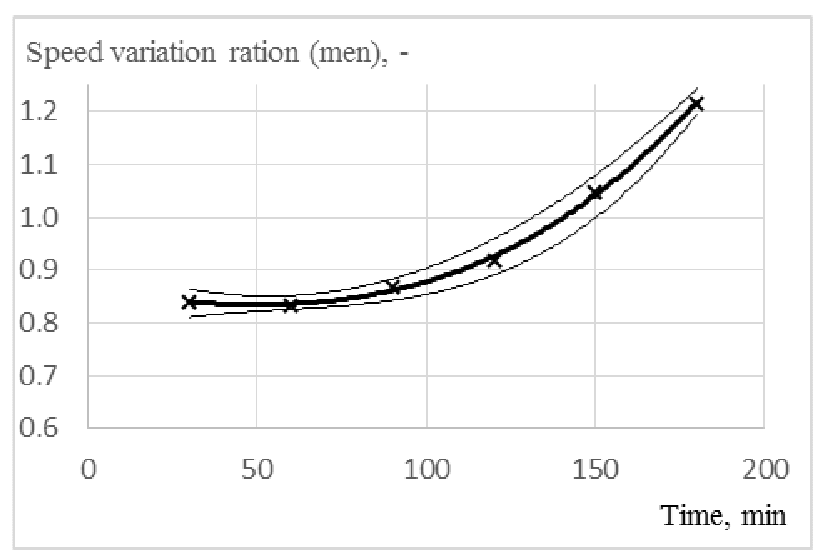

Diagram 11. Speed variation (men)

Table 4. Equations of the fitted curves - speed variation (men)

\begin{tabular}{|c|c|c|c|}
\hline $\begin{array}{l}\text { Type of the } \\
\text { curve }\end{array}$ & $\begin{array}{l}\text { Rank } \\
\text { of } \\
\text { the } \\
\text { curve }\end{array}$ & Equation of the curve & R2 \\
\hline \multirow{3}{*}{$\begin{array}{l}\text { Curve fitted } \\
\text { on the upper } \\
\text { confidence } \\
\text { interval }\end{array}$} & 1 & $0.0025 x+0.71$ & 0.83 \\
\hline & 2 & $2 * 10^{-5} x^{2}-0.0026 x+0.92$ & 0.99 \\
\hline & 3 & $\begin{array}{c}-5^{*} 10^{-8} \mathrm{x}^{3}+4 * 10^{-5} \mathrm{x}^{2}- \\
0.0041 \mathrm{x}+0.96\end{array}$ & 0.99 \\
\hline \multirow{3}{*}{$\begin{array}{l}\text { Curve fitted } \\
\text { on } \\
\text { the data points }\end{array}$} & 1 & $0.0025 x+0.7$ & 0.83 \\
\hline & 2 & $2 * 10^{-5} x^{2}-0.0028 x+0.91$ & 0.99 \\
\hline & 3 & $\begin{array}{c}7 * 10^{-8} \mathrm{x}^{3}+4 * 10^{-6} \mathrm{x}^{2}- \\
0.0009 \mathrm{x}+0.86 \\
\end{array}$ & 0.99 \\
\hline \multirow{3}{*}{$\begin{array}{l}\text { Curve fitted } \\
\text { on the upper } \\
\text { confidence } \\
\text { interval }\end{array}$} & 1 & $0.0024 x+0.68$ & 0.81 \\
\hline & 2 & $3 * 10^{-5} x^{2}-0.0029 x+0.89$ & 0.98 \\
\hline & 3 & $\begin{array}{c}2 * 10^{-7} \mathrm{x}^{3}-3 * 10^{-} \\
5 \mathrm{x}^{2}+0.0022 \mathrm{x}+0.77\end{array}$ & 0.99 \\
\hline
\end{tabular}

Accuracy variation ration (men), -

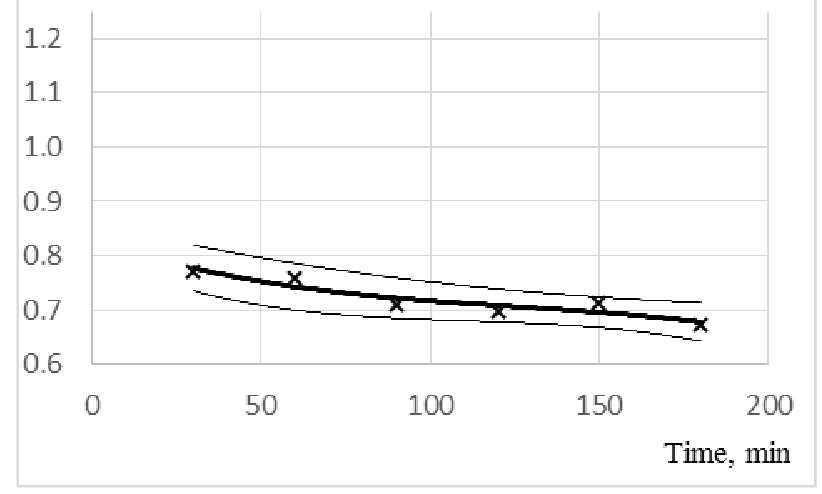

Diagram 12. Accuracy variation (men)

Table 5. Equations of the fitted curves - accuracy variation (men)

\begin{tabular}{|c|c|c|c|}
\hline $\begin{array}{c}\text { Type of the } \\
\text { curve }\end{array}$ & $\begin{array}{c}\text { Rank } \\
\text { of }\end{array}$ & Equation of the curve & R2 \\
\hline
\end{tabular}

\begin{tabular}{|c|c|c|c|}
\hline & $\begin{array}{c}\text { the } \\
\text { curve }\end{array}$ & \\
\hline \multirow{2}{*}{$\begin{array}{c}\text { Curve fitted } \\
\text { on the upper } \\
\text { confidence } \\
\text { interval }\end{array}$} & 1 & $0.0007 \mathrm{x}+0.83$ & 0.83 \\
\cline { 2 - 4 } & 2 & $3 * 10^{-6} \mathrm{x}^{2}-0.0014 \mathrm{x}+0.86$ & 0.93 \\
\hline \multirow{2}{*}{$\begin{array}{c}\text { Curve fitted } \\
\text { on } \\
\text { the data } \\
\text { points }\end{array}$} & 1 & $\begin{array}{c}-4 * 10^{-9} \mathrm{x}^{3}+4^{*} 10^{-6} \mathrm{x}^{2}- \\
0.0015 \mathrm{x}+0.86\end{array}$ & 0.93 \\
\cline { 2 - 4 } & 2 & $-0.0006+0.78$ & 0.84 \\
\cline { 2 - 4 } & 3 & $2 * 10^{-6} \mathrm{x}^{2}-0.0011 \mathrm{x}+0.81$ & 0.87 \\
\hline $\begin{array}{c}\text { Curve fitted } \\
\text { on the upper } \\
\text { confidence } \\
\text { interval }\end{array}$ & 1 & $0.0022 \mathrm{x}+0.83$ & 0.88 \\
\cline { 2 - 4 } & 2 & $-0.0005+0.74$ & 0.74 \\
\cline { 2 - 4 } & 3 & $\begin{array}{c}-40^{-6} \mathrm{x} 2-0.0008 \mathrm{x}+0.75 \\
-4\end{array} 0^{-9} \mathrm{x}^{3}+4 * 10^{-6} \mathrm{x}^{2}-$ & 0.75 \\
\hline
\end{tabular}

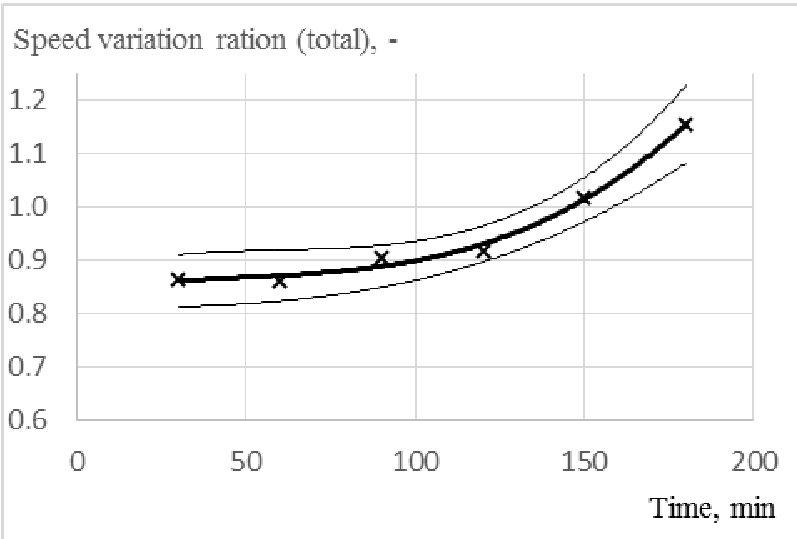

Diagram 13. Speed variation (total)

Table 6. Equations of the fitted curves - speed variation (total)

\begin{tabular}{|c|c|c|c|}
\hline $\begin{array}{l}\text { Type of the } \\
\text { curve }\end{array}$ & $\begin{array}{c}\text { Rank } \\
\text { of } \\
\text { the } \\
\text { curve }\end{array}$ & Equation of the curve & $\mathrm{R} 2$ \\
\hline \multirow{3}{*}{$\begin{array}{l}\text { Curve fitted } \\
\text { on the upper } \\
\text { confidence } \\
\text { interval }\end{array}$} & 1 & $0.0019 x+0.8$ & 0.76 \\
\hline & 2 & $2 * 10^{-5} x^{2}-0.0028 x+0.99$ & 0.97 \\
\hline & 3 & $\begin{array}{c}2 * 10^{-7} \mathrm{x}^{3}-3 * 10^{-} \\
5 \mathrm{x}^{2}+0.0019 \mathrm{x}+0.87\end{array}$ & 0.98 \\
\hline \multirow{3}{*}{$\begin{array}{l}\text { Curve fitted } \\
\text { on } \\
\text { the data } \\
\text { points }\end{array}$} & 1 & $0.0018 x+0.76$ & 0.83 \\
\hline & 2 & $2 * 10^{-5} x^{2}-0.002 x+0.91$ & 0.98 \\
\hline & 3 & $10^{-7} x^{3}-10^{-5} x^{2}+0.001 x+0.84$ & 0.99 \\
\hline \multirow{3}{*}{$\begin{array}{l}\text { Curve fitted } \\
\text { on the upper } \\
\text { confidence } \\
\text { interval }\end{array}$} & 1 & $0.0017 x+0.72$ & 0.89 \\
\hline & 2 & $10^{-5} x^{2}-0.0011 x+0.84$ & 0.99 \\
\hline & 3 & $4 * 10^{-8} \mathrm{x}^{3}+10^{-6} \mathrm{x}^{2}-3 * 10^{-5} \mathrm{x}+0.81$ & 0.99 \\
\hline
\end{tabular}




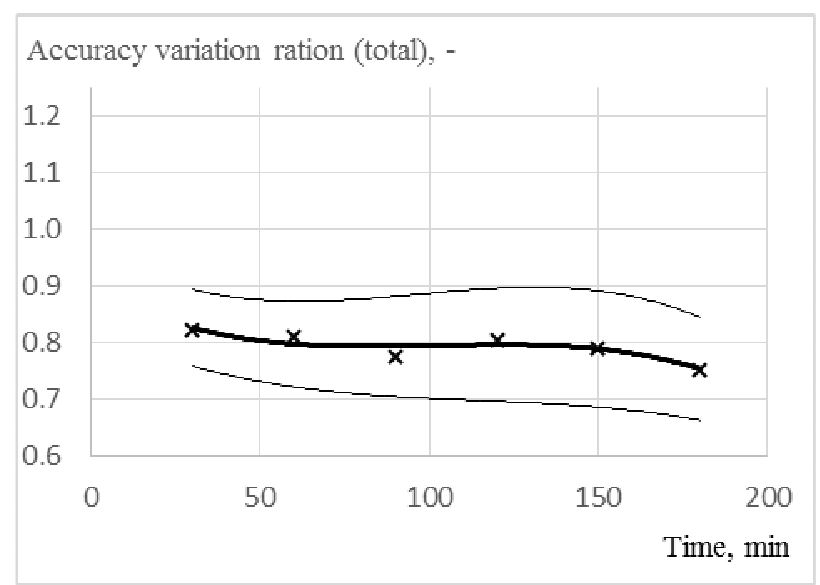

Diagram 14. Accuracy variation (total)

Table 7. Equations of the fitted curves - accuracy variation (total)

\begin{tabular}{|c|c|c|c|}
\hline \multirow{2}{*}{$\begin{array}{c}\text { Type of the } \\
\text { curve }\end{array}$} & $\begin{array}{c}\text { Rank } \\
\text { of } \\
\text { the } \\
\text { curve }\end{array}$ & Equation of the curve & R2 \\
\hline \multirow{2}{*}{$\begin{array}{c}\text { Curve fitted } \\
\text { on the upper } \\
\text { confidence } \\
\text { interval }\end{array}$} & 1 & $0.0002 \mathrm{x}+0.9$ & 0.13 \\
\cline { 2 - 4 } & 3 & $\begin{array}{c}10-7 \mathrm{x} 3+4 * 10-5 \mathrm{x} 2- \\
0.0036 \mathrm{x}+0.97\end{array}$ & 0.53 \\
\hline \multirow{2}{*}{$\begin{array}{c}\text { Curve fitted } \\
\text { on } \\
\text { the data } \\
\text { points }\end{array}$} & 1 & $0.0004 \mathrm{x}+0.83$ & 0.64 \\
\cline { 2 - 4 } & 2 & $8 * 10-7 \times 2-0.0002 \mathrm{x}+0.83$ & 0.65 \\
\hline \multirow{2}{*}{$\begin{array}{c}\text { Curve fitted } \\
\text { on the upper } \\
\text { confidence } \\
\text { interval }\end{array}$} & 2 & $10-7+3 * 10-5 \times 2+0.0033 \mathrm{x}+0.9$ & 0.82 \\
\cline { 2 - 4 } & 3 & $0.0006 \mathrm{x}+0.77$ & 0.8 \\
\cline { 2 - 4 } & 2 & $2 * 10-6 \times 2-0.001 \mathrm{x}+0.78$ & 0.81 \\
\hline
\end{tabular}

Diagram 15 shows the temporal change of speed and accuracy in all 20 human subjects, without pointing out the measurement points and significance intervals. The upper curve shows the change of the speed, the lower curve shows the change of accuracy in time.

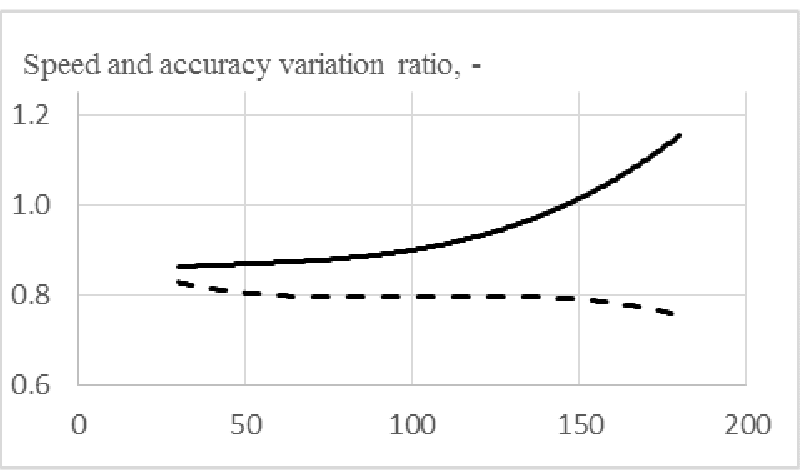

Diagram 15. Temporal change of work efficiency - women and men

\section{Conclusions}

We made a human subject experiment in order to study the combined effect of warm ceiling and draught, on work efficiency, under the following parameters: $\mathrm{DR}=15 \%$ draught and $\mathrm{AS}=5,7,10,12,15{ }^{\circ} \mathrm{C}$. The following conclusions can be made based on the results:

- $\quad$ work speed showed a temporal increase, while work accuracy showed decrease - thus we could easily identify a speed-accuracy compensation;

- the increase of work speed was more pronounces in case of men. This also meant a decrease in accuracy, compared with the results of women. Women were able to keep the speed-accuracy ratio high over a longer period of time then men.

\section{Acknowledgement}

This work was partially supported by the Hungarian National Research, Development and Innovation Office (OTKA Number 124777) and the FIKP artificial intelligence -Smart City program.

Thanks to all the companies which have provided material and professional assistance to the Macskásy climate and comfort laboratory.

\section{References}

1. E. Barna, $\mathrm{PhD}$ T., A sugárzási hömérséklet aszimmetria és a meleg padló együtes hatása a höérzetre (2012)

2. L. Bánhidi L., L. Kajtár, Komfortelmélet (2000)

3. P. O. Fanger, Themal Comfort (1970)

4. TNM Regulation, Determination of the energetical parameters of buildings (2006)

5. J. Toftum, En. Build., Human response to combined indoor environment exposures 34, 601 (2002)

6. J. Toftum, Int. J. Ind. Erg., Draught sensitivity is influenced by general thermal sensation. 34, 601 (2002)

7. D. P. Wyon, M. Ép., Methodology for indoor environment researches. (2003) 